medRxiv preprint doi: https://doi.org/10.1101/2020.04.08.20058032; this version posted April 11, 2020. The copyright holder for this preprint

(which was not certified by peer review) is the author/funder, who has granted medRxiv a license to display the preprint in perpetuity.

It is made available under a CC-BY-NC-ND 4.0 International license .

\title{
Prevalence of anxiety disorder among workers with cancer in Amman, Jordan
}

Abdel Rahman Aref Ali Abu Shreea1, Lee Khuan2, Sharifah Norkhadijah Syed Ismail1, Nasrudin Subhi (KB/PA)3, Sobuh (Moh'd Sobhi) Ahmad Abu-Shanab4, Zaher Juma' Raja Mashrqi4, Irniza Rasdi $1 *$.

1Department of Environmental and Occupational Health, Faculty of Medicine and Health Sciences, Universiti Putra Malaysia, 43400 UPM, Serdang, Selangor, Malaysia.

2Department of Nursing and Rehabilitation, Faculty of Medicine\& Health Sciences, Universiti Putra Malaysia, 43400 UPM, Serdang, Selangor, Malaysia.

3School of Psychology and Human Development, Faculty of Social Sciences and Humanities, National University of Malaysia, Bangi, Malaysia.

4King Hussein Cancer Center, Queen Rania St 202, Amman, Jordan.

*To whom correspondence should be addressed. Email: irniza@upm.edu.my) 
medRxiv preprint doi: https://doi.org/10.1101/2020.04.08.20058032; this version posted April 11, 2020. The copyright holder for this preprint (which was not certified by peer review) is the author/funder, who has granted medRxiv a license to display the preprint in perpetuity. It is made available under a CC-BY-NC-ND 4.0 International license.

\begin{abstract}
Introduction: Cancer is now being recognised as a long term conditions due to advances in treatments that increase the survival rate of patients with cancer to as long as 10 years from the time of the disease. Anxiety is among the commonly discovered psychiatric illness in patients with cancer and is often neglected. Approximately $10 \%$ of patients with cancer are affected with anxiety worldwide. Hence, this study was aimed to determine the prevalence of anxiety disorder and its associated factors among workers with cancer in Jordanian population. Methods: A cross-sectional study was conducted at the King Husain Cancer Centre (KHCC) in Amman, Jordan. Proportional sampling technique was used to obtain the sample population of 355 workers with cancer. Data were collected through self-administered Generalized Anxiety Disorder (GAD-7) questionnaire and analyses were carried out using SPSS version 25. Results: Response rate of $100 \%$ were obtained from the participants. Prevalence of anxiety disorder among workers with cancer was recorded at $20.8 \%$ with male $(23.1 \%)$ having the higher prevalence rate than female $(17.3 \%)$ workers with cancers. A significant difference in anxiety between marital status $(p=0.025)$, types of cancer $(p=0.001)$, treatment types $(p=0.024)$ were observed. A multiple regression was run to predict anxiety disorder from marital status, type of cancer and treatment types. These variables statistically significantly predicted anxiety disorder $\left[\mathrm{F}(3,351)=8.117, p<.001, \mathrm{R}_{2}=0.225\right]$. Conclusion: There is high prevalent of anxiety disorder among workers with cancer in Jordan. Predictors of anxiety among workers with cancer were also identified in this report.
\end{abstract}

Keywords: Anxiety disorder, prevalence, workers, cancer, Jordan. 
medRxiv preprint doi: https://doi.org/10.1101/2020.04.08.20058032; this version posted April 11, 2020. The copyright holder for this preprint

\section{Introduction}

Cancer is the second leading cause of death around the world, and is resulting to an estimated 9.6 million deaths in 2018 especially in low- and middle income countries [1]. The most common cancer risk factor is use of tobacco and is responsible for approximately $22 \%$ of cancer deaths[2]. Hepatitis and human papilloma virus (HPV) that are known as cancer causing infections are responsible for up to $25 \%$ of cancer cases in low- and middle-income countries[3]. The economic impact of cancer is significantly increasing. The total annual economic cost of cancer in 2010 was estimated at approximately US\$ 1.16 trillion [4]. In Jordan, cancer is the second leading cause for death after heart related diseases (Ashraf, \& Ahmad, 2015). Additionally, it is observed that cancer morbidity and mortality is to be increased as young people age. Focusing over the aetiology of cancer, it is observed that tobacco is one of the major causes for cancer in Jordanians (Ahmad, 2015). High prevalence of smoking is linked with high incidents of lung cancer that is most common type of cancer in Jordan. Other common types of cancer observed in Jordan include colon and bladder cancer. In the year 2010, only 41 cases of cancer were registered. However, as compared to past decades, it is realized that new cancer cases diagnosis has increased among Jordanians (MOH, 2017).

Anxiety disorder may negatively affect patients with cancer within the duration of their diagnosis. Jordanian cancer patients are confronted with worries and uncertainties related to the effects of cancer on their life. The fear of pain, progression of the cancer, death, spiritual questioning, and guilt are high in these patients[5]. Anxiety tends to increase as a result of cancer treatment trajectory[6], and is identified as the most reported symptom in patients with cancer. From the initial diagnosis to initiation of treatment, cancer recurrence, and the failure 
medRxiv preprint doi: https://doi.org/10.1101/2020.04.08.20058032; this version posted April 11, 2020. The copyright holder for this preprint

of treatment along with perception of dying increases the overall stress and anxiety in the patients[7]. Hence, anxiety is often termed as a response to cancer diagnosis, which is the normal behaviour towards the initial shock, disbelief, and emotional distress [8]. [9] indicated that the cancer patients continuously worried and fear about their future as well as cancer recurrence. Anxiety has an impact on physiological and psychological health and well-being of an individual, however, the symptoms might differ from individual to individual. Apart from physical pain, and emotional distress, anxiety and depression are common factors affecting cancer patients worldwide. Thus, it is very important to address this problem in especially workers suffering silently with cancer in Jordanian population.

Literatures are limited about the prevalent symptoms of anxiety in Jordanian population. However, several factors have been reported to be linked with anxiety in patients with cancer and these includes social support, sociodemographic and socio-economics variables as well as functional status[10-12]. Factors associated with anxiety in patients with cancer need to be thoroughly investigated to improve their quality of life[10, 13] as well as their health outcome. A number of studies were carried out on anxiety associated with cancer patients, but none has been carried out on workers with cancer particularly among Jordanian population. Thus, this study aimed to determine the anxiety disorder level and its associated factors, explore the sociodemographic, and clinical features of cancer among workers with cancer in Jordanian population. 
medRxiv preprint doi: https://doi.org/10.1101/2020.04.08.20058032; this version posted April 11, 2020. The copyright holder for this preprint

\section{Materials and methods}

\section{Study Design}

In this work, a cross sectional study was carried out in King Husain Cancer Centre (KHCC) from October 2019 to January 2020. [14] stated that cross sectional research design is based on observational research design. Here, the researcher examined the outcomes as well as exposure for research participant at the same time. Participants are selected on the basis of a defined inclusion and exclusion criteria.

\section{Selection criteria}

The eligibility criteria in this research were participants must be the citizen of Jordan and obtained the cancer treatment from King Husain Cancer Centre (KHCC). The patient must be the employee of any organization in Jordan. Whilst workers with cancer disease who are not Jordanian were excluded from the study. Patients who were not attending KHCC for their cancer treatment. Patients with cancer who are not unemployed were also excluded from the study. In addition, patient below 18 years age group and those that are not working in any organization were excluded.

\section{Determination of sample size}

Sample size calculation was made using [15] formula for calculating samples size as below and the highest prevalence of the attribute $(30.3 \%)$ was obtained and used to determine the number of sample required for this study [16]. 
medRxiv preprint doi: https://doi.org/10.1101/2020.04.08.20058032; this version posted April 11, 2020. The copyright holder for this preprint

Sample size $(\mathrm{n})=\mathrm{Z1}^{2}-\alpha / 2 \mathrm{Pq} / \mathrm{d}^{2}$

$=\mathrm{Z1}^{2}-\alpha / 2 \mathrm{P}(1-\mathrm{P}) / \mathrm{d}^{2}$

Where, Z1- $\alpha / 2=$ standard error when $\alpha=0.05(95 \%$ Confidence Interval $)=1.96$

$q=1-P$

$\mathrm{P}=$ prevalence of the attribute $=(30.3 \%)[16]$

$\mathrm{d}=$ Acceptable difference using $5 \%(0.05)$

$\mathrm{N}=$ number of sample size

A total of 325 sample or respondents was required and after adding $10 \%$ (32.5) attrition rate, the sample size was $=357.5 \sim 358$. Therefore, we enrolled 358 workers with cancers in this study.

\section{Sampling method}

The samples are to be drawn from accessible population working class of cancer patients in King Husain Cancer Centre (KHCC). Each of the patients considered independent unit and proportional sampling technique was used to obtain the sample population.

\section{Research instrument}

Data were collected using a self-administered online questionnaire. The questionnaire was divided into five different sections with each section having questions related to its title. In summary, the questionnaire contains socio-demographic section, cancer disease information, workplace support system, work related issues, and the Generalized Anxiety Disorder section scale (GAD-7) that is adopted since it is one of the most widely used diagnostic self-report scales for screening, diagnosis and severity assessment of anxiety disorder. This scale 
medRxiv preprint doi: https://doi.org/10.1101/2020.04.08.20058032; this version posted April 11, 2020. The copyright holder for this preprint

(which was not certified by peer review) is the author/funder, who has granted medRxiv a license to display the preprint in perpetuity. It is made available under a CC-BY-NC-ND 4.0 International license .

comprised of seven questions and it is rated based on the whole scale score that was range from 0 to 21 and cut-off scores for mild, moderate and severe anxiety symptoms are 5, 10 and 15 respectively [17]. This section contains 7 items questions and the rating scale was based on 7 Likert system of measurement ranging from $1=$ strongly disagree to $7=$ strongly agree. A pilot study was conducted using Cronbach's alpha. The GAD-7, WRI and WSS questionnaires were at an alpha $(\alpha)=0.80, \alpha=0.843$, and $\alpha=0.913$ respectively.

\section{Statistical Analysis}

Data analysis was carried out using IBM Statistical Package for Social Sciences (SPSS) version 25. Descriptive statistics such as frequencies, percentages and exploratory analysis were used in normalizing the data and expressed as Mean \pm SD. One way ANOVA and MannWhitney $U$ test were used in analysing normally and not normally distributed data. Multilinear regression were used to analysed predictors for anxiety disorder. The internal reliability of information is examined by use of Pearson correlation and Cronbach alpha test. The alpha value higher than 0.7 is perceived as satisfactory and internal consistency also provides the estimation of test-retest reliability. The significance of such a correlation was tested from $t$-test and $p$-value $<0.05$ was considered statistically significant.

\section{Ethical consideration}

Ethical approval was obtained from the University Ethics Committee for Research involving Human Subjects, Faculty of Medicine and Health Sciences (FMHS), Universiti Putra Malaysia (UPM) with reference number: UPM/FPSK/JKPP/A0426. Permission and approval were also obtained from Institutional Review Board (IRB) of King Husain Cancer Centre (KHCC) with reference number: 19 KHCC 112. Participants were given a written informed 
medRxiv preprint doi: https://doi.org/10.1101/2020.04.08.20058032; this version posted April 11, 2020. The copyright holder for this preprint

(which was not certified by peer review) is the author/funder, who has granted medRxiv a license to display the preprint in perpetuity.

It is made available under a CC-BY-NC-ND 4.0 International license .

consent with an appropriate ethical consideration regarding the information about the study, the right of withdrawal, and protect their confidentiality regarding their identity and the information that they did not wish to disclose.

\section{Results}

\section{Sociodemographic characteristics of the respondents}

A total of 355 workers with cancer were approached in the KHCC during the period of data collection. The response rate of the study were $100 \%$. Table 1 shows the socio-demographic characteristics of the respondents. The mean age of the respondents was 42.3 years $(95 \% \mathrm{Cl}=$ 41.3, 43.4). There was significant difference $(\mathrm{t}=1.921, \mathrm{df}=353, p=0.05)$ between the mean age of male $(43.1$ years, $95 \% \mathrm{Cl}=41.7,44.5)$ and that of female $(41.0$ years, $95 \% \mathrm{Cl}=39.5$, 42.5) respondents in this study. The majority of the respondents were married (78.9\%) and only $14.4 \%$ were single while $3.1 \%$ were divorced. Majority of them had a Bachelor $(57.2 \%)$ with $12.4 \%$ had a high school qualification. In terms of their job role, business was the highest (29.9\%), then followed teacher (20.6\%) and health professional (20.0\%) with only $18.0 \%$ were civilian workers while the least were drivers $(2.3 \%)$. 
medRxiv preprint doi: https://doi.org/10.1101/2020.04.08.20058032; this version posted April 11, 2020. The copyright holder for this preprint (which was not certified by peer review) is the author/funder, who has granted medRxiv a license to display the preprint in perpetuity. It is made available under a CC-BY-NC-ND 4.0 International license

Table 1: Distribution of the respondents according to socio-demographic characteristics $(\mathbf{n}=355)$

Variable(s)
Number

$19-30$

$31-40$

$41-50$

$51-60$

Total

Gender

Male

Female

Total

Marital status

Single

Separated

Divorced

Windowed

Married

Total

\section{Educational level}

Primary school

Intermediate school

High school

Two years college

Bachelor

Postgraduate education

Total

Job role

Business

Civil servant

Driver

Engineer

Health professional

Teacher

Total
50

60.8

39.2

100.0

14.1

31.3

33.0

21.7

100.0

355

14.4

51

0.8

3.1

11

2.8

78.9

280

100.0
4.5

16

5.6

44

12.4

36

10.1

203

57.2

36

10.1

355

100.0

106

29.9

64

18.0

8

2.3

33

9.3

71

20.0

73

20.6

355 
medRxiv preprint doi: https://doi.org/10.1101/2020.04.08.20058032; this version posted April 11, 2020. The copyright holder for this preprint

(which was not certified by peer review) is the author/funder, who has granted medRxiv a license to display the preprint in perpetuity.

It is made available under a CC-BY-NC-ND 4.0 International license .

\section{Clinical characteristics of the respondents}

Table 2 shows the clinical characteristics of workers with cancer. Majority of them $(52.1 \%)$ were of stage II cancer stage and then followed by those in stage III (23.9\%). The remaining patients were of stage I (12.7\%) and stage IV (11.3\%) respectively. In terms of treatment types received by the patients, majority received chemotherapy $(91.5 \%)$ while the remaining have had surgery $(3.7 \%)$, and received immunotherapy (3.4\%) and radiotherapy $(1.4 \%)$. When categorised based on cancer types, majority were of breast cancer (16.9\%), followed by lung (13.2\%), lymphoma (13.0\%), colorectal (11.0\%) and others accounting $10.7 \%$ and the least was cervical (1.7\%). As for the duration of diagnosis of the disease (cancer), majority of the respondents reported having 1-5 months (49.6\%), 251 months and above (40.8\%), 6-50 months duration (6.2\%) and the least were those who were diagnose within 201-250 months $(0.3 \%)$. 
Table 2: Clinical characteristics of the respondents $(n=355)$

Characteristics Number Percentage

$(\%)$

\section{Cancer stage}

Stage I

45

12.7

Stage II

185

52.1

Stage III

85

23.9

Stage IV

40

11.3

Total

Treatment types

Surgery

Chemotherapy

Radiotherapy

Immunotherapy

\section{Type of cancer}

Bladder

Bone

Brain

13

3.7

Breast

60

16.9

Cervical

6

1.7

Leukaemia

Lung

28

Ovarian

Colorectal

Lymphoma

Pancreatic

Stomach

Testicular

3.9

Thyroid

2.0

Others

10.7

Total

\section{Duration of diagnosis}

$1-5$

6-50

51-100

101-150

201-250

251 and above

Total
176 
medRxiv preprint doi: https://doi.org/10.1101/2020.04.08.20058032; this version posted April 11, 2020. The copyright holder for this preprint

(which was not certified by peer review) is the author/funder, who has granted medRxiv a license to display the preprint in perpetuity.

It is made available under a CC-BY-NC-ND 4.0 International license .

\section{Comparison of age based on mean rank according cancer stage}

Table 3 shows the comparison of age based on the mean rank according to the cancer stage.

The mean rank of ALL respondents (178.0) was lower compared with cancer stage III and stage IV but higher compared with cancer stage I and stage II. To determine the difference of mean rank age among cancer stages, one-way ANOVA was carried out. The analysis results showed that there was significant difference among the three stages of cancer in terms of mean rank age $F(109,171)=9.892, p=0.001)$. Patients with stage I and stage II cancer (140.2 vs 168.1) were younger compared with patients with stage III and IV cancer (186.2 vs 249.1) $(p=0.001)$. In contrast, patients with stage II were older than patients with stage I cancer $(p=0.001)$.

Table 3: Comparison of age based on mean rank according cancer stage

\begin{tabular}{llccc}
\hline Cancer stage & n & Mean \pm SD & $\boldsymbol{F}$ statistic (df) & $\boldsymbol{p}$ value* \\
& & & & \\
\hline Stage I & 45 & $140.2 \pm 103.8$ & $9.892(109,171)$ & 0.001 \\
Stage II & 185 & $168.1 \pm 99.5$ & & \\
Stage III & 85 & $186.2 \pm 94.7$ & & \\
Stage IV & 40 & $249.1 \pm 99.4$ & & \\
& & & & \\
\hline
\end{tabular}

*one-way ANOVA

\section{Prevalence of anxiety disorder and its severity}

Table 4 shows the prevalence of anxiety disorders among workers with cancer. From the total of 335 respondents, the overall prevalence of the anxiety disorders was $20.8 \%$. From 74 number of severity, $1.4 \%$ were found to have mild anxiety disorder, $11.5 \%$ were moderately 
medRxiv preprint doi: https://doi.org/10.1101/2020.04.08.20058032; this version posted April 11, 2020. The copyright holder for this preprint

(which was not certified by peer review) is the author/funder, who has granted medRxiv a license to display the preprint in perpetuity.

It is made available under a CC-BY-NC-ND 4.0 International license.

severe and $7.9 \%$ were found to be severe. Severity among these patients is shown in Table 4 below.

Table 4: Severity of symptoms of anxiety disorder among workers with cancer $(n=355)$

\begin{tabular}{lcc}
\hline Anxiety (GAD7) & Frequency & Percentage \\
\hline Mild & 5 & $1.4 \%$ \\
Moderate & 41 & $11.5 \%$ \\
Severe & 28 & $7.9 \%$ \\
Total & 74 & $20.8 \%$ \\
\hline
\end{tabular}

Moreover, this study found higher prevalence rate of anxiety in male (23.1\%) compared to female $(17.3 \%)$ workers with cancers. Among these respondents, there was higher preponderance of those whose marital status were Separated (33.3\%), followed by Widowed (30.0\%), Divorced (27.3\%), Single (17.0\%) and Married (20.7\%). There was also a high proportion of anxiety disorder among workers with cancer whose educational level were intermediate school (35.0\%), high school (27.3\%), two year college (22.2\%), and bachelor (19.7\%). Similarly, anxiety disorder was found to be higher among Engineers (30.3\%), and Business $(25.5 \%)$ then followed by Driver (25.0\%), Civil servant $(20.3 \%)$ and Teachers (16.4\%). Differences in mean of anxiety disorder were also determined, and there was a significant difference in anxiety between marital status $(p<0.05)$, types of cancer $(\mathrm{p}<0.05)$, treatment types $(\mathrm{p}<0.05)$. However, there was no significant difference in anxiety disorder in educational level $(p>0.05)$, job role $(p>0.05)$, cancer stage $(p>0.05)$ and gender $(p>0.05)$ (Table 5). 
Table 5: Comparison of means of anxiety disorder among gender, marital status, educational level, job role, cancer stage, type of cancer and treatment types

\section{Variables \\ Gender}

Male

Female

216

139

$12.1 \pm 2.4$

$11.7 \pm 2.9$

Marital status

Single

Separated

Divorced

Widowed

Married

\section{Educational level}

Primary school

Intermediate school

High school

$13.67 \pm 1.5$

11

$9.64 \pm 1.9$

10

$11.70 \pm 3.5$

280

$12.11 \pm 2.6$$$
0.737(6,348)
$$$$
0.620
$$

$$
\begin{aligned}
& 11.53 \pm 2.3 \\
& 12.10 \pm 2.7 \\
& 11.77 \pm 2.6 \\
& 11.44 \pm 2.5 \\
& 12.00 \pm 2.6 \\
& 12.53 \pm 2.5
\end{aligned}
$$$$
36
$$

Bachelor

203

Post graduate

36

\section{Job role}

Business

Civil servant

106

$11.85 \pm 2.7$

$1.093(5,349)$

0.364

Driver

64

$11.82 \pm 1.9$

Engineer

8

$13.25 \pm 2.8$

33

$12.67 \pm 2.5$

Health professional

$12.00 \pm 2.6$

Teacher

71

$11.69 \pm 2.9$

\section{Cancer stage}

Stage I

$11.80 \pm 2.4$

$1.129(3,351)$

0.337

Stage II

Stage III

85

$11.83 \pm 2.6$

Stage IV

40

$11.40 \pm 2.7$

\section{Type of cancer}

Bladder

Bone

Brain

Breast

60

$10.76 \pm 3.4$

Cervical

$10.70 \pm 2.7$

Leukaemia
6
28

$11.83 \pm 0.9$

$10.96 \pm 2.2$ 
medRxiv preprint doi: https://doi.org/10.1101/2020.04.08.20058032; this version posted April 11, 2020. The copyright holder for this preprint

$\begin{array}{lcc}\text { Lung } & 47 & 12.02 \pm 2.8 \\ \text { Ovarian } & 8 & 13.75 \pm 1.7 \\ \text { Colorectal } & 39 & 12.67 \pm 2.4 \\ \text { Lymphoma } & 46 & 12.52 \pm 2.0 \\ \text { Pancreatic } & 8 & 13.62 \pm 2.1 \\ \text { Stomach } & 12 & 12.50 \pm 2.5 \\ \text { Testicular } & 14 & 12.85 \pm 1.6 \\ \text { Thyroid } & 7 & 15.14 \pm 2.5 \\ \text { Others } & 38 & 11.84 \pm 2.6\end{array}$

\section{Treatment types}

\begin{tabular}{lcccc} 
Surgery & 13 & $13.15 \pm 1.9$ & $3.190(3,351)$ & 0.024 \\
Chemotherapy & 325 & $11.94 \pm 2.5$ & & \\
Radiotherapy & 5 & $13.60 \pm 1.3$ & \\
Immunotherapy & 12 & $10.33 \pm 3.25$ & & \\
\hline
\end{tabular}

*one-way ANOVA

\section{Factors contributing to anxiety disorder}

Table 6 shows data presentation obtain from simple linear regression which demonstrated that among all the independent variables used to predict anxiety disorder, marital status $(\beta=$ $0.227, p<0.038)$, type of cancer $(\beta=0.131, p<0.001)$, and treatment types $(\beta=-0.636, p<$ $0.045)$ have significantly explained or predicted anxiety disorder among workers with cancer. Following a multiple regression analysis (Table 6), it was found that still all the three mentioned variables significantly explained the anxiety disorder. These predictors are types of cancer $(\beta=0.133, p<0.001)$ which seems to have higher effect than both marital status $(\beta$ $=0.197, p<0.036)$, and treatment types $(\beta=-0.689, p<0.029)$ on workers' anxiety disorder. The reported value of the F-statistic $(\mathrm{F}=8.117,<0.001)$ fits the model data. Standardized Regression coefficients are presented in Table 6 to explain the importance of these predictors on anxiety disorder among workers with cancer. The $\mathrm{R}_{2}=0.057$ revealed that a combination of this predictor explained $25.5 \%$ of variance in anxiety disorder. 
Table 6: Predictors of anxiety disorder among workers with cancer

\begin{tabular}{|c|c|c|c|c|c|}
\hline \multirow[t]{2}{*}{ Variable } & \multicolumn{2}{|c|}{$\begin{array}{c}\text { Unadjusted } \\
\text { (Simple linear regression) }\end{array}$} & \multicolumn{2}{|c|}{$\begin{array}{c}\text { Adjusted } \\
\text { (Multiple linear regression) }\end{array}$} & \multirow[b]{2}{*}{ VIF } \\
\hline & B ( $(\beta)$ & $p$ value & $\mathbf{B}(\boldsymbol{\beta})$ & $p$ value & \\
\hline Age & $-0.005(-0.018)$ & 0.766 & - & - & - \\
\hline Gender & $-0.301(-0.051)$ & 0.335 & - & - & - \\
\hline Education & $0.187(0.91)$ & 0.123 & - & - & - \\
\hline Marital status & $0.227(0.125)$ & 0.038 & $0.197(0.109)$ & 0.036 & 1.008 \\
\hline Job role & $-0.018(-0.014)$ & 0.824 & - & - & - \\
\hline Cancer stage & $-0.289(-0.093)$ & 0.094 & - & - & - \\
\hline Type of cancer & $0.131(0.198)$ & $<0.001$ & $0.133(0.202)$ & $<0.001$ & 1.005 \\
\hline Treatment types & $-0.636(-0.105)$ & 0.045 & $-0.689(0.109)$ & 0.029 & 1.011 \\
\hline F value & & & 8.117 & & \\
\hline$P$ value & & & $<0.001$ & & \\
\hline Adj R2 & & & 0.057 & & \\
\hline
\end{tabular}

\section{Discussion}

This work provides the general prevalence and associated factors of anxiety disorder among 355 workers with cancer who were attending King Husain Cancer Centre (KHCC) in Amman, Jordan. We had a 100\% response rate from the participants whose overall meant age was 42.3 years with male at 43.1 years and female aged 41.0 years respectively. More than $70 \%$ of the participants were married and about $60 \%$ of them had a bachelor degree qualification. Business was the major means of their job role followed by teaching professions. The percentage of these sociodemographic variables are consistent and had no much difference with a study by [18] who explored anxiety and depression among diabetic patients in Amman, Jordan. Our results suggest that majority of the workers with cancer in Jordan were married 
medRxiv preprint doi: https://doi.org/10.1101/2020.04.08.20058032; this version posted April 11, 2020. The copyright holder for this preprint

(which was not certified by peer review) is the author/funder, who has granted medRxiv a license to display the preprint in perpetuity. It is made available under a CC-BY-NC-ND 4.0 International license.

and averagely, were educated. Analysis of clinical characteristics of workers with cancer showed that majority of the patients were of stage II (52.1\%) and stage III cancers (23.9\%). And that most of them (91.5\%) received chemotherapy drugs as their treatment types while $16.9 \%$ were of breast cancer type and most of these patients reported to have had 1-5 months (49.6\%) duration of diagnosis. These results suggest high stage tumour is predominant among workers with cancer in Jordan with at least 5 months duration of diagnosis.

However, comparison of these clinical features among workers with cancers is difficult because of the limited studies in this area of research. Hence, this is the first study to report these clinical features in workers with cancer in particularly the Jordanian population. However, cancer staging has been proven to be the most significant prognostic factor for evaluating survival rate[19]. Consistent with other study from Bahrain [20] that demonstrated more cases of patients with cancer were diagnosed at stages II and III and another study carried out in Jordan by [21]who evaluated the epidemiological and survival analysis of Jordanian breast cancer patients from 1997 to 2002. Our findings is contrary to a study conducted in Canada who discovered that about $75 \%$ of patients diagnosed with cancer were of stage I and stage II[20] which is unlike in our study that showed majority of the patients fall in stage II and stage III cancer groups. However, stage II is lower in percentage than stage II group in the Canadian population study. This could be due to the fact that hospitals across Jordan implemented a screening programmes for high risks patients who are mostly stage II to be undergoing mammography in combination with regular clinical examinations. Comparison of age based on the mean rank according to the cancer stages showed that patients with stage I and stage II cancer (140.2 vs 168.1) were younger compared with patients with stage III and IV cancer (186.2 vs 249.1) $(p=0.001)$. In contrast, patients with 
medRxiv preprint doi: https://doi.org/10.1101/2020.04.08.20058032; this version posted April 11, 2020. The copyright holder for this preprint

(which was not certified by peer review) is the author/funder, who has granted medRxiv a license to display the preprint in perpetuity. It is made available under a CC-BY-NC-ND 4.0 International license.

stage II were older than patients with stage I cancer $(p=0.001)$. To best of our knowledge, this is the first population based study that evaluated the impact of age at diagnosis and the clinical features of cancer stages among workers with cancer in Jordan.

Prevalence of anxiety disorder among these workers with cancer was $20.8 \%$ accounting for $23.1 \%$ male who were seems to have higher prevalence rate than female $(17.3 \%)$ workers with cancers. Furthermore, prevalent rate of anxiety were noticed mostly among marital status that were separated, widowed, divorce and single. Likewise, high prevalence was observed among professional engineers and business individuals, drivers, civil servant and teachers. Anxiety disorder varies across marital status, types of cancer, and treatment types. The prevalence found in this study is comparable with a study that carried out a systematic review and meta-analysis to demonstrate the prevalence of major and minor depressions as well as anxiety in patients with cancer[22]. Our findings demonstrated high prevalent of anxiety disorder among workers with cancer than can be found in most of the studies[22, 23]. Multilinear regression analysis showed that anxiety is positively associated with marital status $(p=0.036)$, type of cancer $(p=0.001)$, and treatment types $(p=0.029)$ with combination of these predictors explaining $25.5 \%$ of variance in anxiety disorder. The prevalence of anxiety in patients with cancer in this study were similar to those of the previous findings that report even high elevated symptoms of anxiety [24, 25]. This could be due to different methodological scale used in measuring the anxiety disorder among the patients. In contrast to our report,[26] reported a higher prevalence of anxiety in breast cancer patients accounting for about $46.8 \%$. Our results also identified that married workers with cancer have less symptoms of anxiety. This finding is similar with recent study conducted in Vietnam that evaluated anxiety among patients with cancer through a hospital 
medRxiv preprint doi: https://doi.org/10.1101/2020.04.08.20058032; this version posted April 11, 2020. The copyright holder for this preprint

(which was not certified by peer review) is the author/funder, who has granted medRxiv a license to display the preprint in perpetuity. It is made available under a CC-BY-NC-ND 4.0 International license.

based cross-sectional study [27]. Reason for this is because generally, married patients with cancer perceive more social support than unmarried or separated individuals. Anxiety and depression are frequently diagnosed in patients with cancer and are serve the best way of identifying those patients who are in risk of psychological stress [28, 29]. Moreover, anxiety and depression has been linked with poorer physical function [30] and high risk of high mortality in patients with cancer [31].

This study faced some challenges and limitations. Firstly, the sample may not represent the whole population of workers with cancer in Jordan. Even though the Jordanian population is small, but KHCC serve as the largest hospitals where all patients are refereed from all medical facilities in the country. Secondly, the study did not cover some other clinical features due to inaccurate records that was made available to the researcher.

\section{Conclusion}

This study reports the prevalence of anxiety disorder among workers with cancer who were attending King Husain Cancer Centre (KHCC) in Amman, Jordan. Our findings demonstrated higher prevalent rate of anxiety among these patients. Marital status, type of cancer and treatment types were the major predictors of anxiety among workers with cancer. However, other unknown factors might be the cause for this high prevalent of anxiety which need to be further investigated. This high level of anxiety and distress experienced by workers with cancer is a serious public health issues that required government attention for effective work delivery among workers with cancer. Thus, workers with cancer need to be monitor and screened for anxiety disorder especially when register for clinical check-up as 
medRxiv preprint doi: https://doi.org/10.1101/2020.04.08.20058032; this version posted April 11, 2020. The copyright holder for this preprint

(which was not certified by peer review) is the author/funder, who has granted medRxiv a license to display the preprint in perpetuity.

It is made available under a CC-BY-NC-ND 4.0 International license.

this will help in drastically reducing the distress they might have faced during the diagnostic period.

\section{Funding}

This study is not funded, it is self-finance by the researchers

\section{Conflict of interest}

The authors declare that there is no conflict of interests among them.

\section{Acknowledgments}

The authors extend their special thanks to the management and staff of King Hussain Medical

Centre in Amman, Jordan for allowing us to embarked on this study using their attending patients. We are also indebted to University Ethics Committee for Research involving Human Subjects, Faculty of Medicine and Health Sciences (FMHS), Universiti Putra Malaysia (UPM) for approving the study. 
medRxiv preprint doi: https://doi.org/10.1101/2020.04.08.20058032; this version posted April 11, 2020. The copyright holder for this preprint (which was not certified by peer review) is the author/funder, who has granted medRxiv a license to display the preprint in perpetuity. It is made available under a CC-BY-NC-ND 4.0 International license .

\section{References}

1. Bray F, Ferlay J, Soerjomataram I, Siegel RL, Torre LA, Jemal A. Global cancer statistics 2018: GLOBOCAN estimates of incidence and mortality worldwide for 36 cancers in 185 countries. CA Cancer J Clin. 2018;68:394-424. doi:10.3322/caac.21492.

2. Murray et al. CJL. Global, regional, and national comparative risk assessment of 79 behavioural, environmental and occupational, and metabolic risks or clusters of risks, 19902015: a systematic analysis for the Global Burden of Disease Study 2015. Lancet. 2016;388:1659-724. doi:10.1016/S0140-6736(16)31679-8.

3. Plummer M, de Martel C, Vignat J, Ferlay J, Bray F, Franceschi S. Global burden of cancers attributable to infections in 2012: a synthetic analysis. Lancet Glob Health. 2016;4:e609-16. doi:10.1016/S2214-109X(16)30143-7.

4. Cheikh A, El Majjaoui S, Ismaili N, Cheikh Z, Bouajaj J, Nejjari C, et al. Evaluation of the cost of cervical cancer at the National Institute of Oncology, Rabat. Pan Afr Med J. 2016;23:209. doi:10.11604/pamj.2016.23.209.7750.

5. Baqutayan SMS. The effect of anxiety on breast cancer patients. Indian J Psychol Med. 2012.

6. Grassi L, Spiegel D, Riba M. Advancing psychosocial care in cancer patients. [version 1; peer review: 3 approved]. F1000Res. 2017;6:2083. doi:10.12688/f1000research.11902.1.

7. Smith HR. Depression in cancer patients: pathogenesis, implications and treatment. Oncol Lett. 2015.

8. Trill MD. Anxiety and sleep disorders in cancer patients. EJC supplements. 2013.

9. Zhou J, Feng P, Lu X, Han X, Yang Y, Song J, et al. Do future limitation perspective in cancer patients predict fear of cancer recurrence, mental distress, and the ventromedial prefrontal cortex activity? Front Psychol. 2018;9:420. doi:10.3389/fpsyg.2018.00420.

10. Gonzalez-Saenz de Tejada M, Bilbao A, Baré M, Briones E, Sarasqueta C, Quintana JM, et al. Association between social support, functional status, and change in health-related quality of life and changes in anxiety and depression in colorectal cancer patients. Psychooncology. 2017;26:1263-9. doi:10.1002/pon.4303.

11. Newcomb RA, Nipp RD, Waldman LP, Greer JA, Lage DE, Hochberg EP, et al. Symptom burden in patients with cancer who are experiencing unplanned hospitalization. Cancer. 2020. doi:10.1002/cncr.32833.

12. Shim EJ, Hahm BJ. Anxiety, helplessness/hopelessness and "desire for hastened death" in Korean cancer patients. Eur J Cancer Care (Engl). 2011;20:395-402. doi:10.1111/j.13652354.2010.01202.x.

13. Mitchell AJ, Ferguson DW, Gill J, Paul J, Symonds P. Depression and anxiety in longterm cancer survivors compared with spouses and healthy controls: a systematic review and meta-analysis. Lancet Oncol. 2013;14:721-32. doi:10.1016/S1470-2045(13)70244-4.

14. Bell E, Bryman A, Harley B. Business research methods. 2018.

15. Elashoff JD, Lemeshow S. Sample size determination in epidemiologic studies. Handbook of epidemiology. 2005.

16. Carlson LE, Angen M, Cullum J, Goodey E, Koopmans J, Lamont L, et al. High levels of untreated distress and fatigue in cancer patients. Br J Cancer. 2004;90:2297-304. doi:10.1038/sj.bjc.6601887.

17. Kroenke K, Spitzer RL, Williams JBW, Monahan PO, Löwe B. Anxiety disorders in primary care: prevalence, impairment, comorbidity, and detection. Ann Intern Med. 
medRxiv preprint doi: https://doi.org/10.1101/2020.04.08.20058032; this version posted April 11, 2020. The copyright holder for this preprint (which was not certified by peer review) is the author/funder, who has granted medRxiv a license to display the preprint in perpetuity. It is made available under a CC-BY-NC-ND 4.0 International license .

2007;146:317-25. doi:10.7326/0003-4819-146-5-200703060-00004.

18. Ahmad A, Abujbara M, Jaddou H, Younes NA, Ajlouni K. Anxiety and depression among adult patients with diabetic foot: prevalence and associated factors. J Clin Med Res. 2018;10:411-8. doi:10.14740/jocmr3352w.

19. Greene FL, Sobin LH. A worldwide approach to the TNM staging system: collaborative efforts of the AJCC and UICC. J Surg Oncol. 2009;99:269-72. doi:10.1002/jso.21237.

20. Ugnat AM, Xie L, Morriss J, Semenciw R, Mao Y. Survival of women with breast cancer in Ottawa, Canada: variation with age, stage, histology, grade and treatment. Br J Cancer. 2004;90:1138-43. doi:10.1038/sj.bjc.6601662.

21. Tarawneh M, Arqoub K, Sharkas G. Epidemiology and survival analysis of Jordanian female breast cancer patients diagnosed from 1997 to 2002. Middle East Journal of Cancer. 2011.

22. Mitchell AJ, Chan M, Bhatti H, Halton M, Grassi L, Johansen C, et al. Prevalence of depression, anxiety, and adjustment disorder in oncological, haematological, and palliativecare settings: a meta-analysis of 94 interview-based studies. Lancet Oncol. 2011;12:160-74. doi:10.1016/S1470-2045(11)70002-X.

23. Pitman A, Suleman S, Hyde N, Hodgkiss A. Depression and anxiety in patients with cancer. BMJ. 2018;361:k1415. doi:10.1136/bmj.k1415.

24. Srivastava V, Ansari MA, Kumar A. Study of anxiety and depression among breast cancer patients from North India. Clinical. 2016.

25. Hassan MR, Shah SA, Ghazi HF, Mohd Mujar NM, Samsuri MF, Baharom N. Anxiety and Depression among Breast Cancer Patients in an Urban Setting in Malaysia. Asian Pac J Cancer Prev. 2015;16:4031-5. doi:10.7314/APJCP.2015.16.9.4031.

26. Calderon C, Carmona-Bayonas A, Hernández R, Ghanem I, Castelo B, Martinez de Castro E, et al. Effects of pessimism, depression, fatigue, and pain on functional healthrelated quality of life in patients with resected non-advanced breast cancer. Breast. 2019;44:108-12. doi:10.1016/j.breast.2019.01.012.

27. Truong DV, Bui QTT, Nguyen DT, Moore J. Anxiety Among Inpatients With Cancer: Findings From a Hospital-Based Cross-Sectional Study in Vietnam. Cancer Control. 2019;26:1073274819864641. doi:10.1177/1073274819864641.

28. Niedzwiedz CL, Knifton L, Robb KA, Katikireddi SV, Smith DJ. Depression and anxiety among people living with and beyond cancer: a growing clinical and research priority. BMC Cancer. 2019;19:943. doi:10.1186/s12885-019-6181-4.

29. Car J, Zycińska J, Lasota W. Assessment of psychological distress and depression in cancer patients. Przeglad epidemiologiczny. 2012.

30. Faller H, Strahl A, Richard M, Niehues C, Meng K. Symptoms of depression and anxiety as predictors of physical functioning in breast cancer patients. A prospective study using path analysis. Acta Oncol. 2017;:1-5. doi:10.1080/0284186X.2017.1333630.

31. Batty GD, Russ TC, Stamatakis E, Kivimäki M. Psychological distress in relation to site specific cancer mortality: pooling of unpublished data from 16 prospective cohort studies. BMJ. 2017;356:j108. doi:10.1136/bmj.j108. 